\title{
Terra-cotta figurines from the Roman theatre of Malaga (Spain): An archaeometric study
}

\author{
J. M. COMPAÑA ${ }^{1}$, A. CABEZA ${ }^{1}$, M. A. G. ARANDA ${ }^{2}$, L. LEÓN-REINA ${ }^{3 *}$, M. CORRALES $^{4}$, M. P. CORRALES \\ 'Departamento de Química Inorgánica. Universidad de Málaga. 29071-Málaga, Spain \\ ${ }^{2}$ CELLS-ALBA Synchrotron. Carretera BP 1413, Km. 3,3. 08290-Cerdanyola del Vallès, Barcelona, Spain \\ ${ }^{3}$ Servicios Centrales de Apoyo a la Investigación. Universidad de Málaga. 29071-Málaga, Spain \\ ${ }^{4}$ Delegación Provincial de Cultura de Málaga. Consejería de Cultura. Junta de Andalucía. 29015- Málaga, Spain \\ ${ }^{5}$ Departamento de Arqueología e Historia Medieval. Universidad de Málaga. 29071-Málaga, Spain \\ *Corresponding Author: lauralr@uma.es
}

\begin{abstract}
A series of 22 figured Phoeno-Punic and Roman terra-cottas, of high relevant archaeological and patrimonial values, have been studied. The samples were recovered in the Roman Theatre of Malaga (Spain). A thorough analysis including stereomicroscopy, elemental analysis by WDXRF, mineralogical analysis by XRPD coupled with the Rietveld method, and SEM, has been carried out. Highly diluted fused glass beads probed to be enough for the X-ray fluorescence analyses, minimizing the damage to the samples. For selected samples, in addition to the classical use of the Rietveld method, the G-factor external-standard approach has been employed to get full quantitative crystalline and amorphous phase analysis. The analytical results allow proposing a local/regional provenance for the main part of the samples, being a relevant data for several artifacts, not contextualized due to stratigraphic alterations in the site. In addition, some relevant samples, for instance a theatrical mask fragment (TRC005), are likely foreign. The overall amorphous is not negligible in phase quantification, accounting for up to $50 \mathrm{wt} \%$. Technologically, all terra-cotta samples are similar, made of calcareous clays, fired at $\sim 700-950^{\circ} \mathrm{C}$.
\end{abstract}

Keywords: Archaeometry, Archaeological terra-cottas, Diffraction methods, Microscopy, Iron age, Roman period.

\section{Las figurillas de terracota del Teatro Romano de Málaga (España): Un estudio arqueométrico}

Se han estudiado 22 terracotas figuradas feno-púnicas y romanas, de alto valor arqueológico y patrimonial. Las muestras proceden de las excavaciones del Teatro romano de Málaga (España). El análisis realizado incluye estereomicroscopía, análisis elemental mediante WDXRF, análisis mineralógico cuantitativo mediante el método de Rietveld de los datos de XRPD y SEM. Para minimizar el daño realizado a las muestras, se prepararon perlas muy diluidas, que han demostrado ser suficientes para los análisis de fluorescencia de rayos-X. Para muestras selectas, además del análisis usual mediante el método de Rietveld, se ha utilizado el método del estándar externo mediante el factor-G para obtener análisis cuantitativos de fases cristalinas y amorfas. Los resultados analíticos permiten proponer una procedencia local/regional para la mayor parte de las muestras, siendo esta información de gran interés para algunas piezas descontextualizadas debido a alteraciones estratigráficas en el yacimiento. Adicionalmente, algunas piezas relevantes, como un fragmento de máscara teatral (TRC005) son posiblemente piezas de importación. La cuantificación de la fracción amorfa indica que la magnitud de ésta no puede ser despreciada en las cuantificaciones, llegando a ser cercana al $50 \mathrm{wt} \%$. Tecnológicamente, todas las terracotas son muy similares, fabricándose en arcillas calcáreas cocidas entre unos 700 y $950{ }^{\circ} \mathrm{C}$.

Palabras clave: Arqueometría, Terracotas arqueológicas, Métodos de difracción, Microscopía, Edad del hierro, Periodo Romano.

\section{INTRODUCTION}

The Roman Theatre of Malaga is located in the city of Malaga, in southern Spain (Figure 1). Since the Second Punic War, the city of Malaka had an increased relevance as exporting harbor for minerals as well as fish sauces in the flourishing Roman trade $(1,2)$. This economic activity led, in the Roman Period, to the whole reconstruction of the previous city centre, placed on the slope of the Alcazaba hill (3), with a series of public buildings. Among those, the Roman Theatre stands out. It was discovered in 1951 and, since 1995, a systematic recovery program is being carried out (4). Some excavations have also been carried out in the adjacent areas (Ibn Gabirol gardens and Alcazabilla Street, which also were part of the complex). The current study of the archaeological findings is more surprising than expected, revealing a high relevance. This space, full of sacred connotations in the Phoeno-Punic phase of the city (c $6^{\text {th }}-2^{\text {nd }} c$. BC), was also the place in which a thermae was built in the Roman-Republican period (c $2^{\text {nd }}-1^{\text {st }}$ c. BC). This building finally left place to the Theatre in the 
beginning of the Roman Empire. So far, only selected results are published $(5,6)$ but a full report is in progress. The site has been permanently occupied for more than 2500 years. Thus, the complexity in some areas of the site and the levels superimposition make any attempt of data interpretation quite challenging. In addition, the excavation process has been very slow and long (over 50 years), so evolution in methodology makes a revision of former interpretations compulsory. The Theatre and its surroundings have suffered deep changes in their configuration as wrote above, as well as dramatic stratigraphic alterations (such as deep trenches or pits in the Middle Age, c $13^{\text {th }}-14^{\text {th }}$ c. AD). Hence, the Archaeological study of the recovered materials is extremely complex and demands an objective (quantitative) approach in some cases to understand relationships among the samples.

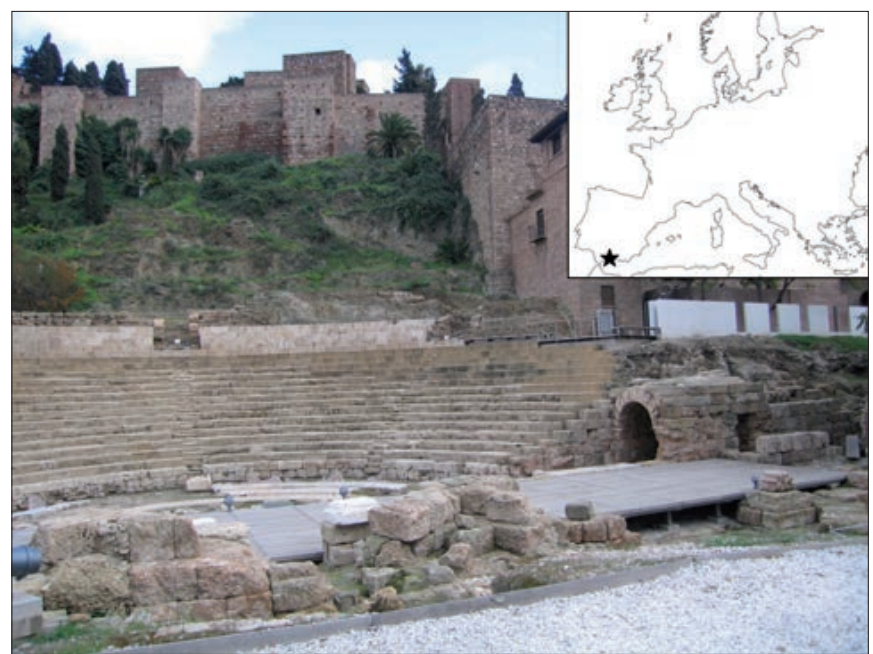

Figure 1. The Roman Theatre of Malaga.

The terra-cotta figurine fragments found in the diverse excavation campaigns in the Roman Theatre of Malaga, gathered among many other objects, make an outstanding collection. This kind of earthenware was usually of local production, but it is known that there were also importations from other parts of the Empire, like the Italian Peninsula (7). The terra-cotta findings in the Iberian Peninsula show them as clear heir to their Greek, Phoenician and Iberian ancestors. In particular, the use of architectural terra-cotta roof tiles as well as the two-sided roofs in some public buildings terra-cottas was gradually generalized in Roman Hispania, but with clear pre-Roman precedents in cities such as Emporion, San Martín de Ampurias (8). The prototypes used for many buildings were those from the Italian Peninsula, especially in the sacred architecture. In this way, it is well known in the Roman improvement of old Greek peninsular cities (Emporion), Punic (f.i. Carthago Nova, nowadays Cartagena, Murcia), cities of Roman origin such as Italica (Santiponce, Sevilla), Carteia (San Roque, Cádiz) as well as other Iberian settlements (9). It is at the end of the Roman Republic and the beginning of the Roman Empire when those kinds of architectural terra-cottas became so popular and findings are usual both in public and private environments (i.e. domestic or funerary). Nevertheless, attribution to particular buildings, chronology, fabrication processes or even their mere provenance is not usually easy. The recovery in the area of several thymiaterion ( 3 among the analyzed samples) has suggested the presence of an urban
Sanctuary in the Phoeno-Punic Malaka (10), in use up to the $1^{\text {st }}$ c. BC. A medium sized terra-cotta representing an acephalous female bust has been related to this sanctuary (11).

In addition to the architectural terra-cottas there are other small-sized figurines usually found in the aedicula or lararia of Roman houses, mixing decorative and religious functions. It is not easy the distinction between decorative or religious functions or simply toys. The typology of the Hispanic terracottas is clearly inspired in the classical divinities like Magna Mater, Ceres, Venus, Minerva or Jupiter, in addition to other of Eastern divinities, closer to the local customs, like Attis (12). Together with the Gods, other masculine or feminine representations as well as animals or even little articulated dolls are common from the $1^{\text {st }}$ to the $3^{\text {rd }} \mathrm{c}$. AD in domestic, sacred and funerary environments $(13,14)$.

Some terra-cottas have been found in domestic/productive sites in the garum factories of Carteia and El Majuelo (Almuñécar, Granada) whereas those found in Cañada Honda (Italica, Santiponce, Sevilla), Osuna (Sevilla) and El Rinconcillo (Algeciras, Cádiz) are related to pottery production centers. Inside a public context some female busts found in a thermae of Orippo (Dos Hermanas, Sevilla) and inside a private context those terra-cottas from the Villa del Paturro (Cartagena, Murcia) are worth citing. Some other relevant examples are the female figurines dressed with stola and palla recovered in Ilerda (Lleida) and some from Baelo Claudia (Bolonia, Cádiz), unfortunately from an unknown context. Probably the best known examples are those from sanctuaries such as Castellar de Santisteban (Jaén), Castrejón de Capote (Higuera la Real, Badajoz), Cerro de San Pedro (Badajoz) and Priego de Córdoba and Cerro Muriano (Córdoba). In some cases there is a doubt about the last example, which could also be related to a funerary context, mainly cremation graves (14). In any case, the high concentration of these terra-cottas in the site, in contrast with the surroundings and even the rest of the Spanish south coast from the Strait of Gibraltar to Almeria is highly relevant, so a specific study seems necessary.

The geological surrounding of the archaeological site is mainly composed of clayey Quaternary sediments, sometimes of large thickness. The settlement is placed on the slope of the Alcazaba hill, which is constituted of Siluric limestones, greywackes, and phyllites (15). Those low metamorphic phyllites and mica schists are very characteristic of the eastern coastal region of Malaga $(16,17)$, and are usually present as inclusions in the raw material used to produce pottery.

In this work, we present a full analysis of 22 terra-cottas found in the Roman Theatre of Malaga. These samples belong to several types, associated from late Phoenician to Roman levels, but all of them are unusual findings. The aim of this study is to confirm or discard the homogeneity of the samples, checking their chemical and technological similarities. An archaeometric approach has been followed in order to study their mineralogical compositions and their firing temperatures as well as their probable provenances.

\section{MATERIALS AND METHODS}

\subsection{Description of samples}

The current systematic study of the materials recovered in the archaeological excavations in the Roman Theatre of Malaga, is revealing a high relevance for some of them. Among 
TABLE I. BRIEF DESCRIPTION OF THE ANALYZED SAMPLES

\begin{tabular}{|c|c|c|c|c|c|}
\hline Sample & Description & Chronology & Levels & Paste & Pigment \\
\hline TRC001 & Bust fragment? & Late Republic-Early Empire & Interpretation Centre (2007) & Whitish, fine-grained & - \\
\hline TRC002 & Robed male torso & Unknown & 2005 Campaign & Reddish, coarse & - \\
\hline TRC003 & Facing mask & Punic-Republican (?) & S. Aditus (1999 Cmp.) & Whitish, fine-grained & - \\
\hline TRC004 & Head fragment & Late Empire & 1999 Campaign & Reddish, fine-grained & - \\
\hline TRC005 & Theatrical mask fragment? & Early Empire & Ibn Gabirol gardens & Whitish, fine-grained & - \\
\hline TRC006 & Theatrical mask fragment? & Early Empire & Ibn Gabirol gardens & Yellowish, fine-grained & - \\
\hline TRC007 & Male relief & Roman Republic & 2006 Campaign & Reddish, coarse & - \\
\hline TRC008 & Human head fragment & Unknown & Unknown (Old cmp.) & Brownish, very coarse & - \\
\hline TRC009 & Male statuette head & Late Republic & Alcazabilla (2008 Cmp.) & Reddish, fine-grained & - \\
\hline TRC010 & Bust base? Thymiaterion? & $2^{\text {nd }}-1^{\text {st }} c . A D(?)$ & Interpretation Centre (2007) & Whitish, fine-grained & Red \\
\hline TRC011 & Theatrical mask fragment? & Unknown & 1999 Campaign & Reddish, fine-grained & - \\
\hline TRC013 & Human head fragment & Late Empire & Scaena (2003 Cmp.) & Reddish, fine-grained & - \\
\hline TRC014 & Human head fragment & Augustus Principate & N. wall (2009 Cmp.) & Whitish, fine-grained & - \\
\hline TRC015 & Robed male torso & Augustus Principate & N. wall (2009 Cmp.) & Brownish, fine-grained & - \\
\hline TRC016 & Architectural relief & Early Empire & N. wall (2009 Cmp.) & Whitish, fine-grained & - \\
\hline TRC017 & Female statuette & $\begin{array}{c}\text { Unknown (up to Middle } \\
\text { Age) }\end{array}$ & Medieval pit in S. Aditus & Brownish, fine-grained & - \\
\hline TRC018 & Human head fragment & Early Empire (?) & Emiral pit (2009 Cmp.) & Reddish, fine-grained & - \\
\hline TRC019 & Thymiaterion? & Early Empire (?) & Interpretation Centre (2007) & Reddish, fine-grained & - \\
\hline TRC020 & Thymiaterion? & Unknown & 2003 Campaign & Pale brown, fine-grained & $\begin{array}{l}\text { Varnished, } \\
\text { black }\end{array}$ \\
\hline TRC021 & Human head fragment & Late Empire & Scaena (2003 Cmp.) & Brownish, fine-grained & - \\
\hline
\end{tabular}

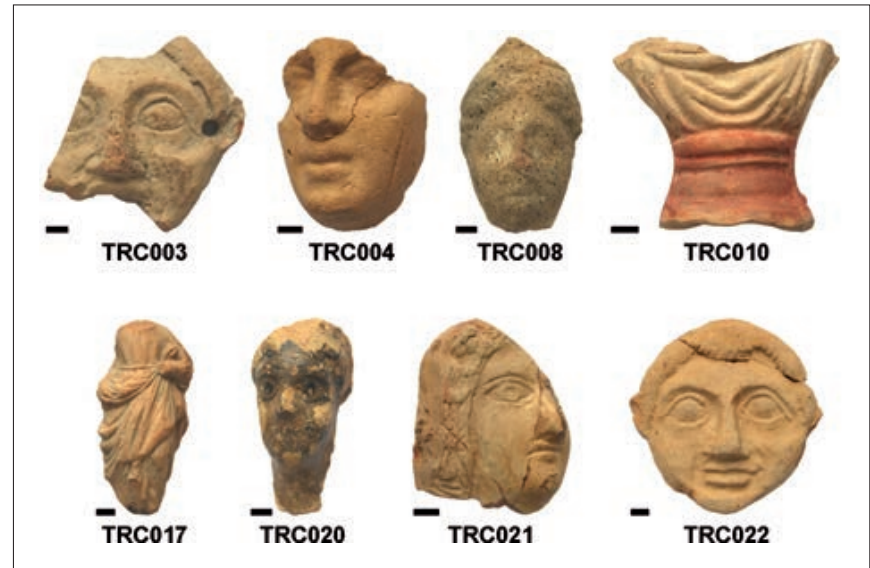

Figure 2. Selected pictures of the analyzed terra-cottas. Bar length $=1 \mathrm{~cm}$.

those, a series of 22 small figured terra-cottas stands out. Therefore, a specific archaeological study is being carried out. The archaeological signatures are too complex, so they have been replaced for an acronym (TRC) followed of a correlative three-digit code, from TRC001 to TRC022. A comprehensive archaeological description of the terra-cottas is beyond the scope of this work, so only a brief description is given in Table $\mathrm{I}$, including some comments about the fabrics. In addition, selected terra-cottas are pictured in Figure 2. The chronologies of the samples is not clear in all cases due to strata alterations, and are being revised to constrain the intervals. For instance, 3 samples (TRC017, TRC018, TRC020) were found in pits breaking into the former levels and, hence, mixed with very dissimilar materials. Nevertheless it is clear that all samples are related to the urban environment of Malaka and the Theatre itself. Therefore, the search for relationships among the samples was needed in order to better understand the collection.

\subsection{Sample preparation}

Due to the high archaeological and patrimonial value of the studied terra-cottas, only very small fragments were carefully cut by using a Struers Minitom water-refrigerated precision trim saw $(\sim 0.1-0.5 \mathrm{~g})$. The broken pieces were characterized by optical stereomicroscopy in order to get a visual macroscopic characterization. Subsequently, the small pieces were reduced to very fine powder in an agate mortar. The powders were analyzed by: i) wavelength-dispersive X-ray fluorescence (WDXRF) in order to study the chemical composition of the pastes; and ii) laboratory X-ray powder diffraction (XRPD) coupled with the Rietveld method in order to study the phase assemblage of the pastes. In two cases, the samples were large enough to save a fraction for a scanning electron microscopy (SEM) in order to study the microstructures including the degree of sintering.

\subsection{Analytical methods}

\subsubsection{STEREOMICROSCOPY}

Freshly broken surfaces obtained after sampling were observed and described by using an Olympus SZX7 

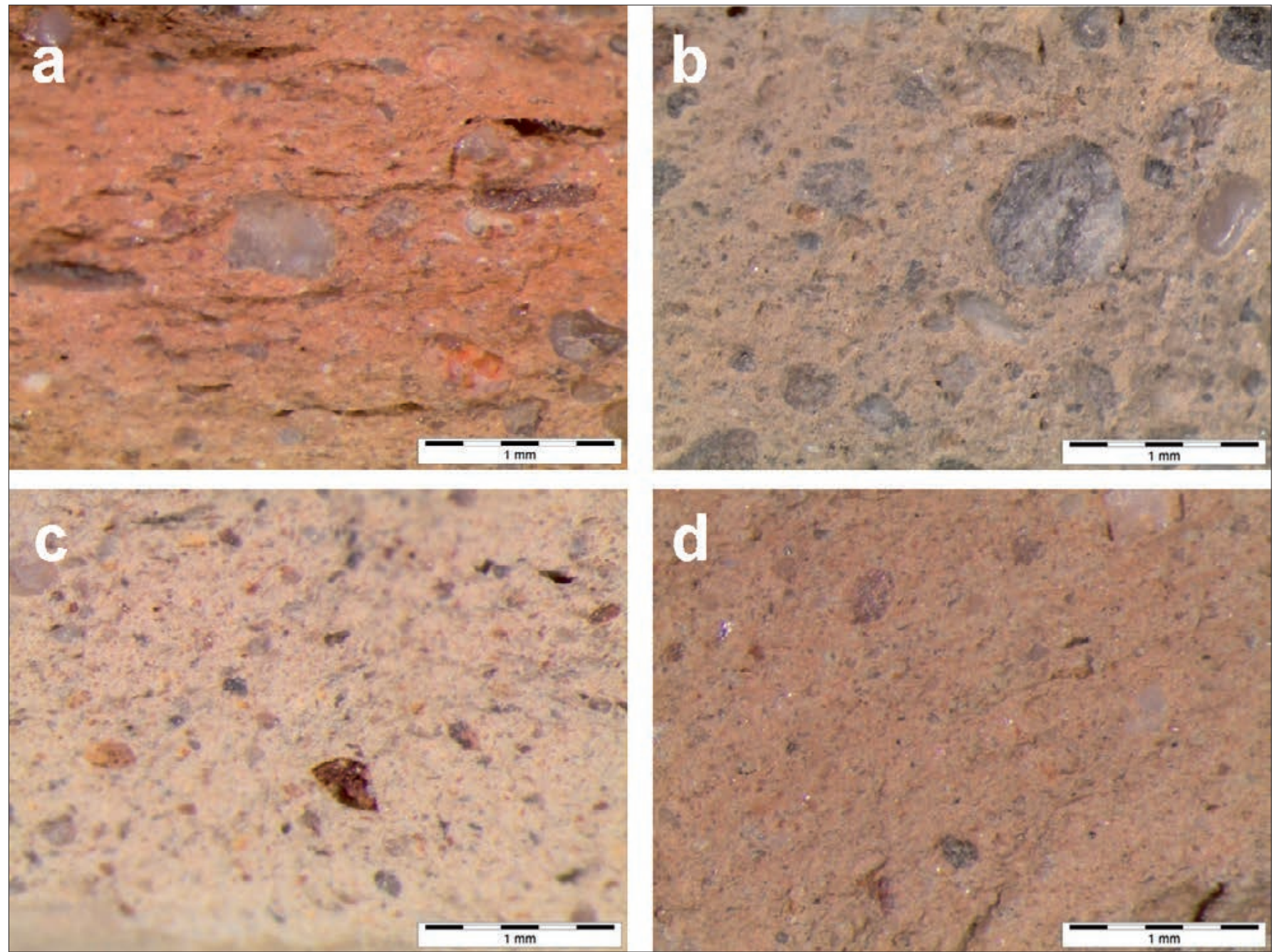

Figure 3. Optical micrographs of selected samples: a) TRC007; b) TRC008; c) TRC012; d) TRC018.

stereomicroscope (See Figure 3). In addition, microphotographs were taken at 10X and 20X magnifications with an Olympus SC30 camera coupled to the stereomicroscope. This camera was PC controlled by Olympus $\mathrm{CELL}^{\wedge} \mathrm{A}$ software (Version 3.3).

\subsubsection{CHEMICAL ANALYSES (WDXRF)}

Quantitative chemical analyses were performed at Servicios Científico-Técnicos, Universidad de Oviedo (Oviedo, Spain). In advance, losses on ignition (LOI) were measured for all samples but TRC009, which was too small. Fused glass beads of the samples were prepared in a PANalytical PerlX3 instrument. The available amount of sample was small, so a high dilution to get an easy-to-use bead size was needed ( $0.1 \mathrm{~g}$ of dried powdered sample $+5.0 \mathrm{~g}$ of lithium tetraborate flux). Each sample was kept for $3 \mathrm{~min}$ at $800{ }^{\circ} \mathrm{C}$, in an oxidizing atmosphere, and then for 5 minutes at $1100{ }^{\circ} \mathrm{C}$. The obtained beads were analyzed by using a PANalytical PW2404 WDXRF spectrometer. Due to the dilution, a new calibration of the spectrometer was necessary. On the one hand, a complete fine calibration of the instrumental parameters was essential for each assembled channel: analytic line, primary filter, collimator, analyzer crystal, exciting conditions $(\mathrm{kV}$ and $\mathrm{mA})$ and detector. The optimal measurement time to obtain good trace detection limits was found to be $30 \mathrm{~min}$. On the other hand, a whole set of beads of rock certificate reference materials was made to perform an accurate calibration for such highly diluted samples. This procedure led to true quantitative chemical data, even with the used dilution. Nevertheless, $\mathrm{S}$ and $\mathrm{Cl}$ contents may be less accurate, due to possible volatilization during the firing losses. The chemical analysis results, expressed as oxides wt \% (major and minor components) and ppm (traces) are given in Table II.

The compositional data from Table II were processed statistically in order to check their homogeneity using MATLAB®. Lack of homogeneity in the analyzed sample is likely due to different raw materials and, therefore, different provenances may be suspected (18-20). First of all, the $\mathrm{P}_{2} \mathrm{O}_{5}$ content was checked, because high phosphorous content usually indicates external organic contamination, i.e. lixiviation of bones if the sample was recovered from a grave $(21,22)$. The highest $\mathrm{P}_{2} \mathrm{O}_{5}$ content is $1.37 \%$ for TRC019, so it can be reasonably accepted that there is not significant external contamination. The compositional matrix given in Table II, excluding $\mathrm{P}_{2} \mathrm{O}_{5}, \mathrm{SO}_{2}, \mathrm{Cl}, \mathrm{Cu}$ and $\mathrm{Pb}$, to avoid possible interferences, has been transformed into log-ratios, as previously reported $(23,24)$. Firstly, the variation matrix of this D-dimensional space was calculated using Equation 1.

$$
\mathbf{T}=\left[\left[_{i j}\right]=\left[\operatorname{var}\left\{\operatorname{og}\left(x_{i} / x_{j}\right)\right\} \cdot i, j=1, \ldots, D\right]\right.
$$


TABLE II. QUANTITATIVE WDXRF ELEMENTAL ANALYSIS OF THE STUDIED SAMPLES EXPRESSED AS OXIDE WT \% (MAJOR AND MINOR COMPONENTS) AND PPM (TRACES)

\begin{tabular}{|c|c|c|c|c|c|c|c|c|c|c|c|c|c|c|c|c|c|c|c|c|c|c|c|}
\hline \multirow[t]{2}{*}{ Sample } & \multicolumn{12}{|c|}{ Major and minor components ( wt \%) } & \multicolumn{11}{|c|}{ Traces (ppm) } \\
\hline & L.O.I. & $\mathrm{Na}_{2} \mathrm{O}$ & $\mathrm{MgO}$ & $\mathrm{Al}_{2} \mathrm{O}_{3}$ & $\mathrm{SiO}_{2}$ & $\mathrm{P}_{2} \mathrm{O}_{5}$ & $\mathrm{SO}_{3}$ & $\mathrm{~K}_{2} \mathrm{O}$ & $\mathrm{CaO}$ & $\mathrm{TiO}_{2}$ & $\mathrm{MnO}$ & $\mathrm{Fe}_{2} \mathrm{O}_{3}$ & $\mathrm{Cl}$ & $\mathrm{Cr}$ & $\mathrm{Ni}$ & $\mathrm{Cu}$ & $\mathrm{Zn}$ & $\mathbf{R b}$ & $\mathrm{Y}$ & $\mathrm{Sr}$ & $\mathrm{Zr}$ & Ва & $\mathrm{Pb}$ \\
\hline TRC001 & 1.66 & 0.86 & 2.56 & 15.04 & 60.64 & 0.74 & 0.06 & 3.23 & 7.94 & 0.75 & 0.07 & 6.27 & n.d. & 110 & 49 & 249 & 125 & 124 & 23 & 304 & 195 & 413 & 256 \\
\hline TRC002 & 10.79 & 0.63 & 1.58 & 11.51 & 56.60 & 0.25 & 0.09 & 2.56 & 10.31 & 0.63 & 0.05 & 4.77 & 233 & 60 & 40 & 844 & 110 & 102 & 19 & 206 & 180 & 499 & 73 \\
\hline TRC003 & 3.25 & 0.82 & 2.42 & 15.34 & 61.37 & 0.33 & 0.11 & 3.09 & 6.19 & 0.78 & 0.07 & 6.08 & n.d. & 106 & 53 & 135 & 119 & 129 & 23 & 259 & 182 & 442 & 83 \\
\hline TRC004 & 7.32 & 1.01 & 2.13 & 14.13 & 57.26 & 0.35 & 0.18 & 2.96 & 7.82 & 0.73 & 0.06 & 5.83 & 741 & 80 & 59 & 132 & 126 & 115 & 19 & 245 & 186 & 315 & 34 \\
\hline TRC005 & 14.47 & 0.87 & 4.12 & 11.55 & 45.27 & 0.59 & 0.28 & 2.59 & 14.80 & 0.51 & 0.08 & 4.59 & n.d. & 97 & 48 & 1336 & 136 & 105 & 20 & 423 & 102 & 440 & 159 \\
\hline TRC006 & 6.68 & 0.92 & 2.27 & 14.77 & 57.94 & 0.42 & 0.26 & 3.11 & 7.05 & 0.79 & 0.05 & 5.55 & n.d. & 101 & 47 & 136 & 143 & 134 & 24 & 276 & 203 & 579 & 126 \\
\hline TRC007 & 5.86 & 0.47 & 2.19 & 14.05 & 55.67 & 0.25 & 0.15 & 2.83 & 11.98 & 0.70 & 0.07 & 5.61 & n.d. & 94 & 3 & 85 & 203 & 118 & 20 & 281 & 158 & 590 & 103 \\
\hline TRC008 & 6.36 & 0.88 & 1.96 & 12.60 & 59.53 & 0.60 & 0.31 & 2.75 & 8.80 & 0.64 & 0.06 & 5.30 & 655 & 66 & 40 & 100 & 115 & 108 & 17 & 280 & 158 & 410 & 77 \\
\hline TRC009 & 0.00 & 0.73 & 2.34 & 16.24 & 63.71 & 0.37 & 0.17 & 3.22 & 6.01 & 0.85 & 0.09 & 6.23 & n.d. & 120 & 67 & 121 & 127 & 133 & 22 & 375 & 223 & 517 & 237 \\
\hline TRC010 & 13.43 & 0.55 & 2.10 & 12.88 & 50.60 & 0.22 & 0.14 & 2.82 & 11.54 & 0.62 & 0.06 & 4.93 & n.d. & 87 & 46 & 91 & 103 & 115 & 21 & 229 & 152 & 322 & 62 \\
\hline TRC011 & 3.98 & 0.70 & 2.04 & 16.66 & 60.81 & 0.26 & 0.10 & 3.43 & 4.49 & 0.88 & 0.07 & 6.42 & 282 & 110 & 53 & 61 & 122 & 155 & 25 & 154 & 205 & 502 & 59 \\
\hline TRC012 & 5.26 & 0.54 & 2.36 & 14.63 & 56.64 & 0.41 & 0.04 & 3.18 & 10.26 & 0.74 & 0.06 & 5.75 & n.d. & 99 & 42 & 80 & 73 & 108 & 25 & 286 & 169 & 490 & n.d. \\
\hline TRC013 & 10.02 & 0.50 & 2.03 & 14.39 & 53.50 & 0.25 & 0.06 & 3.00 & 9.64 & 0.70 & 0.06 & 5.40 & 3031 & 91 & 50 & 61 & 115 & 116 & 19 & 252 & 154 & 432 & 143 \\
\hline TRC014 & 4.91 & 0.77 & 2.43 & 15.08 & 59.47 & 0.39 & 0.04 & 3.16 & 6.60 & 0.78 & 0.08 & 0.11 & n.d. & 113 & 40 & 43 & 110 & 131 & 26 & 325 & 192 & 431 & 561 \\
\hline TRC015 & 8.36 & 0.52 & 2.07 & 12.93 & 55.25 & 0.53 & 0.25 & 2.89 & 11.52 & 0.63 & 0.06 & 4.86 & n.d. & 79 & 34 & 45 & 103 & 111 & 17 & 308 & 149 & 380 & 240 \\
\hline TRC016 & 5.95 & 0.93 & 2.57 & 14.69 & 55.57 & 0.51 & 0.10 & 2.99 & 9.79 & 0.76 & 0.06 & 5.92 & 152 & 110 & 42 & n.d. & 73 & 128 & 18 & 366 & 204 & 446 & 62 \\
\hline TRC017 & 5.07 & 0.87 & 2.67 & 15.18 & 54.69 & 0.27 & 0.08 & 2.96 & 11.21 & 0.76 & 0.07 & 6.00 & n.d. & 110 & 47 & 50 & 91 & 130 & 26 & 332 & 194 & 296 & 358 \\
\hline TRC018 & 4.92 & 0.83 & 2.45 & 16.02 & 55.31 & 0.49 & 0.12 & 3.45 & 8.99 & 0.74 & 0.06 & 6.47 & 471 & 97 & 34 & 84 & 00 & 78 & 27 & 244 & 151 & 414 & n.d. \\
\hline TRC019 & 9.25 & 0.72 & 3.25 & 14.43 & 52.90 & 1.37 & 0.20 & 3.06 & 7.74 & 0.76 & 0.09 & 6.05 & 191 & 81 & 27 & 118 & 186 & 120 & 23 & 201 & 195 & 528 & 225 \\
\hline TRC020 & 1.34 & 0.92 & 2.53 & 14.77 & 61.06 & 0.55 & 0.08 & 3.07 & 8.70 & 0.76 & 0.06 & 5.96 & 192 & 102 & 38 & 41 & 96 & 136 & 24 & 309 & 207 & 483 & 261 \\
\hline TRC021 & 3.52 & 1.35 & 2.59 & 16.48 & 55.37 & 0.21 & 0.15 & 3.39 & 9.01 & 0.78 & 0.07 & 6.75 & 1932 & 88 & 41 & n.d. & 109 & 141 & 27 & 247 & 201 & 497 & 34 \\
\hline TRC022 & 2.87 & 0.91 & 2.39 & 14.15 & 62.43 & 0.25 & 0.15 & 3.05 & 6.89 & 0.73 & 0.08 & 5.92 & 390 & 76 & 68 & 30 & 116 & 120 & 21 & 238 & 205 & 448 & 115 \\
\hline
\end{tabular}

The D-th element which minimizes the variance of the obtained log-ratios was found to be $\mathrm{SiO}_{2}$. Then, the compositional matrix was transformed using Equation 2.

$$
\mathbf{y}=\log \left(\mathbf{x}_{-D} / x_{D}\right)
$$

Where $\mathbf{y}$ is the transformed compositional vector and $\mathbf{x}_{-D}$ is a vector which, for each sample, contains the (D-1) compositions as variables, excluding $\mathrm{SiO}_{2}$, and $x_{D}$ is the $\mathrm{SiO}_{2}$ content of that sample. Then a dendrogram of squared Euclidean distances, UPGMA clustering method, was calculated (Figure 4). This clustering method is regarded as relatively robust and reliable (25). The cophenetic correlation coefficient is a measurement of how faithfully the clustering distances of a dendrogram represent the distance matrix of the original dataset used (equal to 1 for complete concordance). Its value for this dendrogram is 0.8448 , high enough to consider that it describes accurately the dataset.

\subsubsection{MINERALOGICAL ANALYSES (XRPD)}

XRPD data for the pastes were collected at Servicios Centrales de Apoyo a la Investigación (SCAI) of the University of Málaga (Spain) on a PANanalytical X'Pert PRO MPD diffractometer. The powder patterns were recorded in BraggBrentano reflection geometry by using a Ge (111) primary monochromator $\left(\mathrm{CuK} \alpha_{1}\right)$ and the $X^{\prime}$ Celerator detector. The XRPD patterns were taken between 5 and $80^{\circ}(2 \theta)$ with a step size of $0.017^{\circ}(2 \theta)$. The X-ray tube worked at $45 \mathrm{kV}$ and $40 \mathrm{~mA}$ and the samples were rotated during the measurement in order to enhance the particle statistic. All XRPD data treatments (phase identification and mineralogical quantification) were

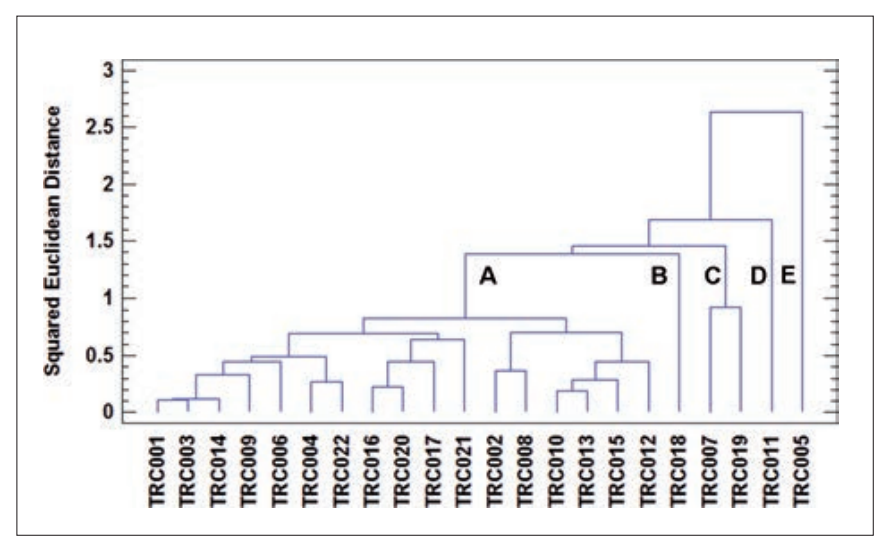

Figure 4 Dendrogram of squared Euclidean distances, UPGMA linkage method, calculated using WDXRF data.

carried out with PANalytical HighScore Plus 2.2.d software. For four samples (TRC004, TRC009, TRC014, TRC022), the measurements were collected together with an external crystalline standard (measured in the same conditions), a thick polished slice of highly crystalline quartz from Maddina, Western Australia, to determine the amorphous phase content (see 'Mineralogical analysis' section below).

Chemical analysis of the samples is not sufficient to study the technology of pottery fabrication $(18-20,26)$. For instance, similar elemental compositions may give rise to different potteries as the mineralogical phase assemblage depends upon the raw clay mineralogy and the firing temperature. XRPD is a key technique to investigate the mineralogical phase assemblage within a potsherd (27-29). The analysis of 
Table III. Minerals present in the studied pastes. Acronyms, Powder Diffraction File codes (PDF) and Inorganic Crystal Structures Database (ICSD) CODES ARE SUMMARIZED

\begin{tabular}{|c|c|c|c|}
\hline Crystalline Phase & Acronym & PDF & ICSD \\
\hline Albite & Pl & $01-076-0927$ & 34917 \\
\hline Anorthite & Pl & $01-076-0948$ & 34742 \\
\hline Anorthoclase & Kfs & $01-076-0803$ & 73446 \\
\hline Calcite & Cal & $01-081-2027$ & 30522 \\
\hline Diopside & Px & $01-075-1092$ & 24588 \\
\hline Gehlenite & Gh & $01-073-2041$ & 24791 \\
\hline Hematite & Hem & $01-073-2234$ & 34986 \\
\hline Microcline & Kfs & $01-076-0918$ & 68547 \\
\hline Muscovite & Mca & $01-080-0742$ & 90145 \\
\hline Quartz & Qtz & $01-070-3755$ & 82086 \\
\hline Rutile & Rt & $01-089-0555$ & 87447 \\
\hline Sericite & Mca & $01-089-6216$ & \\
\hline
\end{tabular}

diffractometric data gives rise to complementary information. Initially, the different phases have been identified by comparing the diffraction peaks present in the patterns with the individual patterns stored in Powder Diffraction File 2, (www.icdd.com). The comparison algorithm is also included in the HighScore Plus software. Once the crystalline phases have been identified, they were quantified using direct Rietveld Quantitative Phase Analysis, RQPA (30,31). The Inorganic Crystal Structure Database codes for the crystal structures used in this analysis are given in Table III. This method is a powerful tool in archaeometric studies as those characterizing pottery, stone and building materials (32-36). It must be underlined that March-Dollase preferred orientation correction was employed when appropriate (i.e. partially dehydroxilated mica minerals and calcite). Some minerals are too similar to be distinguished by Rietveld analysis, like intermediate members of the plagioclase feldspars. Hence, the results are usually expressed as totals for related mineral groups (Kfs, Mca and $\mathrm{Pl}$ ). It must be also underlined that in the direct/basic approach, the Rietveld phase scale factors are transformed to phase fractions by assuming full content of the computed crystalline phases. So, not amorphous content can be determined. The mineralogical data for the pastes, obtained following this methodology, are given in Table IV. Figure 5 displays two Rietveld plots representative of the studied terra-cottas. The Rietveld plot for TRC001, Figure 5 top, is characteristic of terra-cottas fired at relatively high temperatures, see Table IV. Low contents of calcite and clay and relatively high contents of plagioclase and pyroxene (high-temperature products) are evident. Conversely, the Rietveld plot for TRC010, Figure 5 bottom, is characteristic of terra-cottas fired at relatively low temperatures, see Table IV. In this case, high contents of calcite and clay are clear.

When the Rietveld scale factors are directly transformed to phase contents, RQPA gives the mineralogical composition neglecting the amorphous content, and, therefore, referred to $100 \%$ of crystalline computed material. Several methods have been proposed to quantify this amorphous content, mainly based on the addition of a known amount of an internal crystalline standard $(37,38)$. On the other hand, the use of G-factor approach is based on the use of an external crystalline standard (39). This method was first proposed in late eighties,

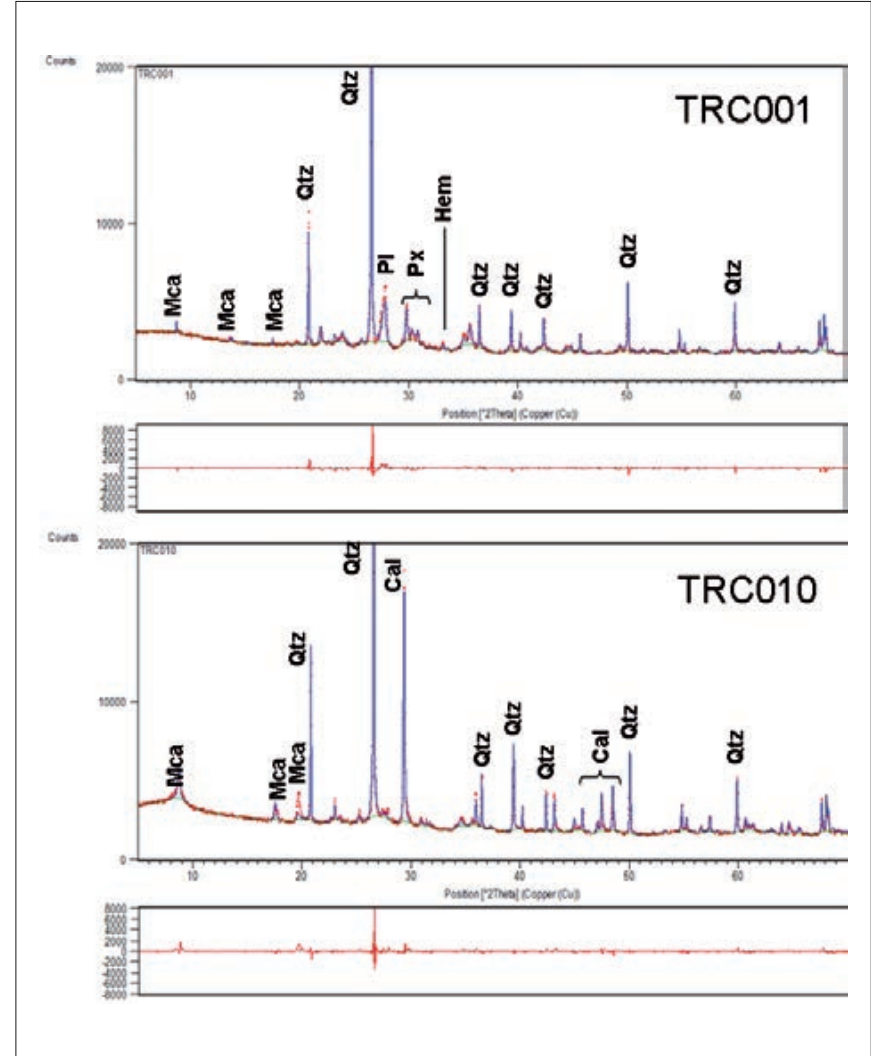

Figure 5. Observed (dots), calculated (full line) and difference (bottom) powder patterns for the Rietveld refinement of XRPD data for TRC001 (representative of high temperature firing) and TRC010 (representative of low temperature firing) with main peaks labeled.

but its full potential is being examined now. A comprehensive discussion of amorphous quantification has been recently given $(40,41)$. The internal standard method requires large sample consumption (it is mixed with a standard), and expensive standards such as $\mathrm{Al}_{2} \mathrm{O}_{3}$-NIST. So, the internal standard method is usually not advisable for archaeometric purposes which commonly involve high number of samples. In contrast, the use of a suitable external standard does not mean sample or standard consumption, and it is much easier 
TABLE IV. MinerAlogicAl COMPOSITION WT \%, REFERRED TO 100 WT \% OF CRYSTALLINE PHASE CONTENT, OF THE STUDIED SAMPLES FROM DIRECT RQPA (INCLUDING THE ERROR AFFECTING THE LAST DIGIT, BETWEEN ROUND BRACKETS), AND ESTIMATED FIRING TEMPERATURES ( $\left.{ }^{\circ} \mathrm{C}\right)$.

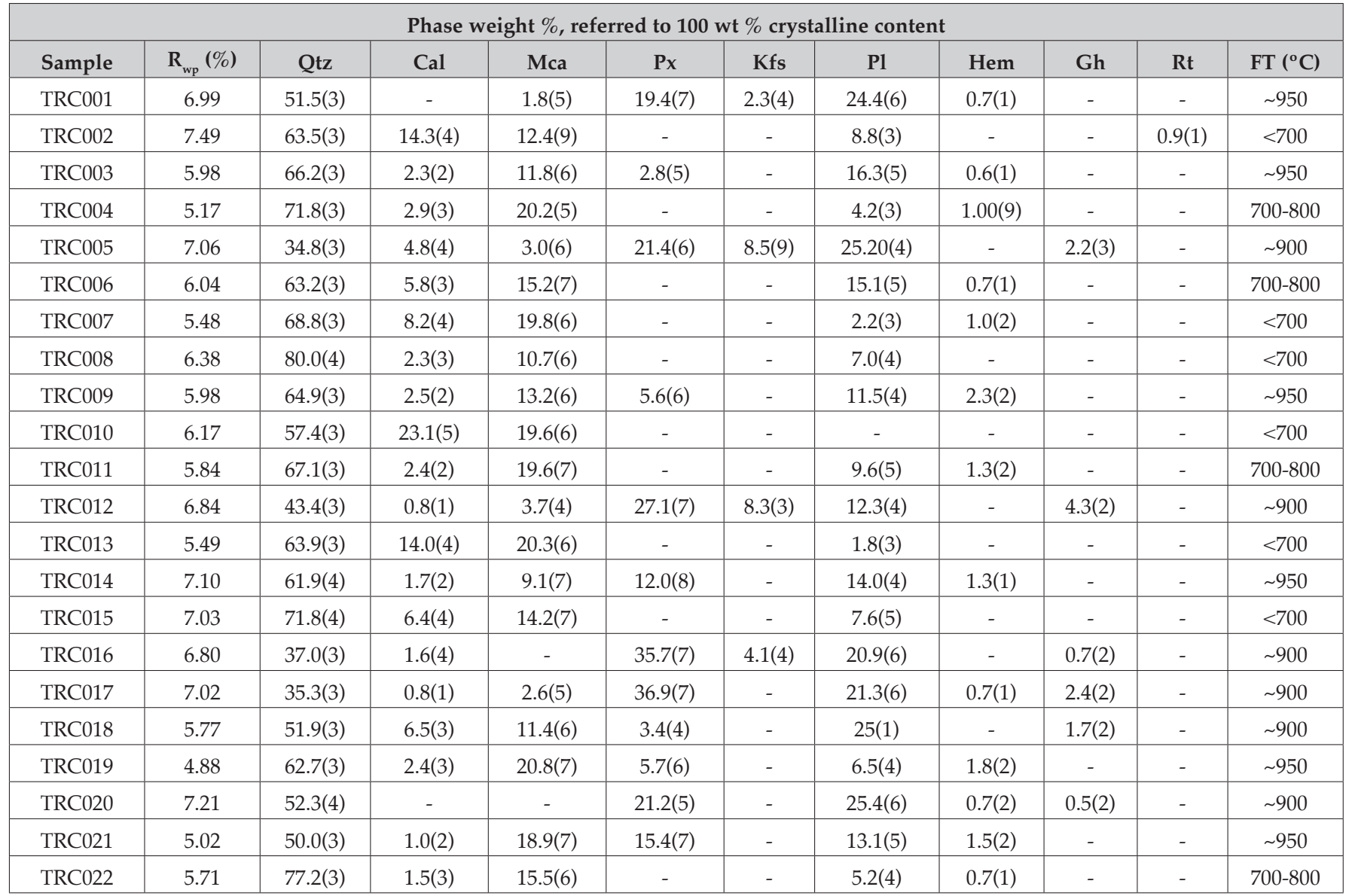

to use for a high number of samples. Despite its potential advantages, to the best of our knowledge, this method does not seem to have been applied to Archaeological ceramics. It is based on the calculation of a $G$ factor for an external standard of known crystallinity measured in exactly the same experimental conditions, using Equation 3,

$$
G=S_{S t} \frac{\rho_{S t} V_{S t}^{2} \mu_{S t}^{*}}{C_{S t}}
$$

where $S_{S t}=$ Rietveld scale factor of the standard, $\rho_{S t}=$ density of the standard, $V_{S t}=$ unit-cell volume of the standard, $C_{S t}=$ weight fraction of the standard (ideally $100 \mathrm{wt} \%$ ), and $\mu_{s t}^{*}=$ Mass Attenuation Coefficient (MAC) of the standard. The calculated $G$ factor represents a calibration factor for the whole experimental setup. Then, the sample concentration in the sample is calculated using Equation 4,

$$
C_{j}=S_{j} \frac{\rho_{j} V_{j}^{2} \mu_{\text {sample }}^{*}}{G}
$$

where the average MAC $(\mu)$ of the sample (from the XRF analysis) must be used. The amorphous content is calculated using Equation 5,

$$
\% \text { Amorphous }=100-\sum_{j} C_{j}
$$

\subsubsection{MICROSTRUCTURAL ANALYSIS (SEM)}

In addition, two small pieces (TRC008 and TRC021) were gold-metalized in a JEOL Ion Sputter JFC-1100 device for about 10 minutes. Then, they were imaged in a JEOL JSM-6490LV scanning electron microscope using secondary electrons. The observations were carried out operating at $20 \mathrm{kV}$, using 1000X magnification.

\section{RESULTS AND DISCUSSION}

\subsection{Stereomicroscopy}

The first analytical step was the visual comparison and classification of the pastes at 10X, 20X and $40 \mathrm{X}$ magnifications. The tiny damage allowed to this set of samples ruled out the possibility of using thin-sectioning methodology. So, the optical study/classification is just qualitative. A range of variability was detected in color, grain size and porosity (for selected images see Figure 3). A brief description of the visual paste characteristics for each sample is given in Table I. In addition to these qualitative descriptions, some remarks must be done. The presence of rounded fragments of dark, laminar rocks was detected as the main inclusion in the coarse-grained paste of sample TRC008 (Figure 3b). These fragments are virtually identical to those in the soil of the Theatre having been, therefore, previously classified as phyllite 
TABLE V. Full RIETVELD QUANTITATIVE PHASE ANALYSIS WT \%, INCLUDING THE AMORPHOUS CONTENT, DERIVED FROM THE G FACTOR METHOD

\begin{tabular}{|c|c|c|c|c|c|c|c|c|c|}
\hline Sample & $\mathbf{R}_{\text {wp }}(\boldsymbol{\%})$ & MAC $\left(\mathbf{c m}^{2} / \mathbf{g}\right)$ & Qtz & Cal & Mca & Pl & Px & Hem & Amorphous \\
\hline TRC004 & 5.17 & 52.92 & 31.9 & 0.3 & 9.0 & 1.9 & - & 0.4 & 57 \\
\hline TRC009 & 5.98 & 54.25 & 31.2 & 1.2 & 6.5 & 5.5 & 2.7 & 1.1 & 52 \\
\hline TRC014 & 7.10 & 53.21 & 30.7 & 0.9 & 4.6 & 6.9 & 5.9 & 0.6 & 50 \\
\hline TRC022 & 5.71 & 53.53 & 34.4 & 0.7 & 7.0 & 2.3 & - & 0.3 & 55 \\
\hline
\end{tabular}

(15). This is a highly characteristic inclusion of Phoenician and Phoeno-punic potteries from the coast of Malaga and Velez-Malaga, and points out to local/regional provenance for this sample $(42,43)$. Therefore, it was also considered as regional 'reference' material for the XRF analysis. In addition, this is also a possible inclusion in other samples such as TRC003 and TRC007 (Figure 3a). In these two cases, the inclusion sizes were too fine to allow confirmation without thin-sectioning. It is also significant to underline the presence of both coarse- and fine-grained terra-cottas. The inclusions of the finer fabrics are not easy to identify (e.g. Figure $3 \mathrm{c}$ and Figure $3 \mathrm{~d}$ ) but, even so, some resemblance to amphorae fabrics recovered in the Theatre can be found.

\subsection{Chemical analysis}

5 clusters may be defined, noted A-E in Figure 4. As stated above, TRC008 is a local/regional production, so those samples closely clustered (cluster A) are also likely regional. It is significant to find out that TRC007 (cluster C) is not very closely clustered to TRC003 or TRC008, despite certain visual similarities, as pointed out above. In the Iberian-found Phoenician and Phoeno-punic pottery, the archaeological evidence available up to date show that phyllite inclusions are indicative of a geological origin on the coastal area of Malaga province, maybe including a part of Granada. Even so, by means of petrographic studies, it is known that there are small differences among the Phoenician pastes along the coast, which may also show slight chemical differences, but still being local to regional productions $(44,45)$. Therefore, it is needed a wider study of the coastal ceramic production in Southern Spain. This type of studies is currently being carried out, for Phoenician productions, by the Madrid section of the Deutsche Archäologische Institut (46). Additionally, the outliers B (TRC018) and E (TRC005) are likely foreign importations. The XRF data are different enough for those samples, and there are additional evidences. Both are fragments of high-quality theatrical masks. From an archaeological point of view, it would not be surprising to find out importations in such specific items. Moreover, the paste of the latter sample resembles to that of some Roman amphorae found close to the Roman Theatre which, taking into account their typology, are very likely foreign (italian?). Unfortunately, it is not possible to ensure the provenance for these samples, yet. Some of the uncertain samples may be from Ancient settlements along the South coast of Spain, in which amphorae and/or other potteries production is known. The presence of similar terra-cottas recovered in the surroundings of Gadir, nowadays Cadiz, suggests a possible provenance that needs to be checked in the future (47).

\subsection{Mineralogical analysis}

All analyzed pastes are Ca-rich, see Table II. In the firing process of calcareous pastes, Fe ions incorporate mainly into the structures of gehlenite and pyroxenes giving a whitish to brownish color rather than forming red hematite in an oxidizing firing, depending on the iron oxide size $(18,20,48,49)$. Nevertheless, small amounts of hematite may crystallize with high oxidizing firings, so this phase is also present in several samples. In general, a good correlation between the higher firings and the paler pastes was found. The firing temperature, FT, of ceramics can be estimated within a certain range by using XRPD data $(18,20,26,50$ 52). Although FT estimations are widely made and used, sometimes are criticized (53). In any case, FT estimations are useful to understand the possible mineralogical dissimilarities within a selected sample. The approximate FT given in Table IV are estimated by using experimental data of an on-going research project about the clays from Malaga bay used by Ancient potters, which is being reported now (54). Furthermore, some comments about this issue were published in a previous work (28).

The described procedure for amorphous quantification was tested in samples TRC004, TRC009, TRC014 and TRC022. We used these samples as there was enough material (about $300 \mathrm{mg}$ ) and the infinite thick sample approach is indispensable as the scale factors are transformed to phase fractions by using the G-factor previously obtained from a standard of infinite thickness, i.e. all X-rays diffracting in the volume of the sample. The obtained results are given in Table V. The calculated amorphous contents are around 50 wt \%, which are fully consistent with the estimated high firing temperatures reported in Table IV. A wider work fully devoted to the application of the G-method to the analysis of archaeological ceramics, including the determination of their amorphous contents, is currently being finished and it will be reported elsewhere.

\subsection{Scanning electron microscopy}

For two terra-cottas, TRC008 and TRC021, the samples pieces were big enough to allow an additional SEM study. In spite of their low number, it was interesting to observe their degree of sintering and check its concordance with the diffractometric study. The samples were observed and compared at 500X and 1000X magnifications. In Figure 6, selected images of the pictures taken at 1000X are shown. The degree of sintering for TRC008 is clearly lower than that of TRC021, as it is noticed by the pseudo-laminar remaining microstructure of the former. Conversely, TRC021 displays a glassier microstructure. These observations are in agreement with the estimated firing temperatures for both samples. 

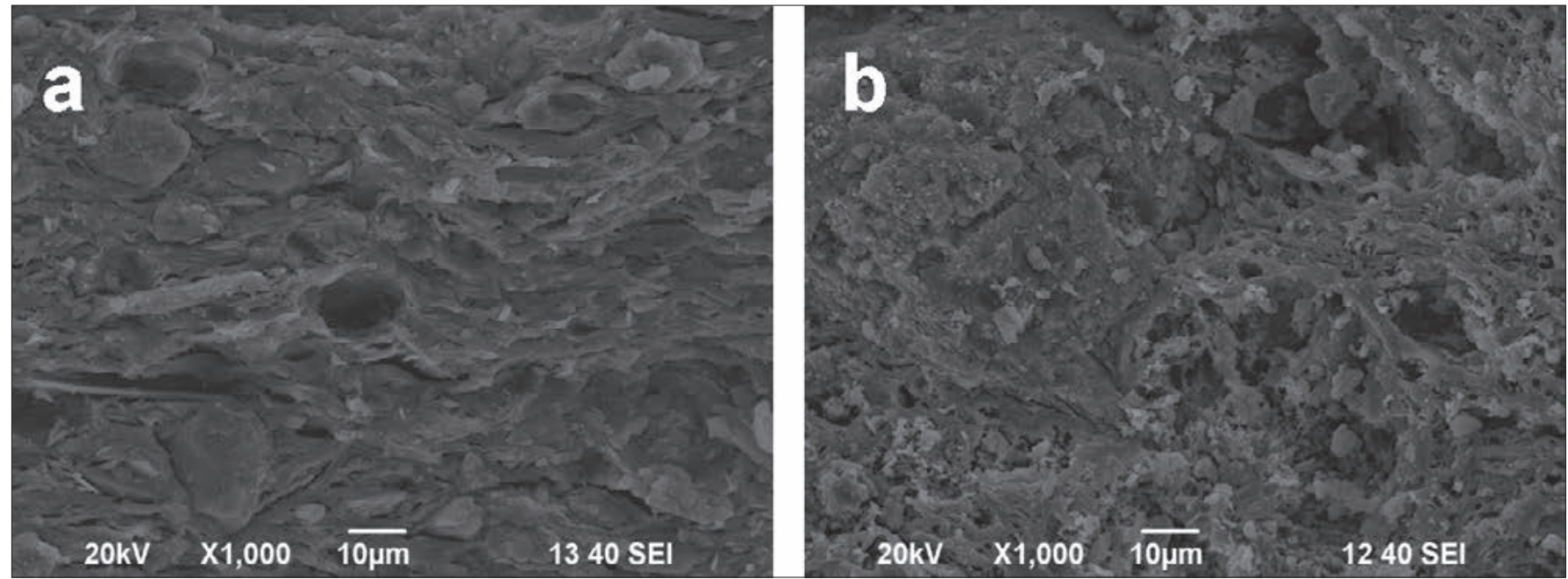

Figure 6. SEM images for the pastes TRC008 (a) and TRC021 (b).

\section{SUMMARY AND CONCLUSIONS}

A full analysis of 22 figured terra-cottas found in the Roman Theatre of Malaga, of high archaeological and patrimonial value, have been carried out by using Stereomicroscopy, WDXRF and XRPD coupled with RQPA. Additionally, SEM characterization has been applied to two samples. This analysis provided useful archaeological information linking the origins of several findings out of a clear context such as TRC017, TRC018 and TRC019, recovered from pits mixed with later findings. Despite the wide range of chronologies for the analyzed pieces in such a relevant public space, it is surprising that only a few different origins were found. This is even more surprising taking into account the high relevance of Malaka as an exporting and importing harbor, which is well known. Other ceramic findings in the site show a massive importation of potteries such as the terra sigillata italica (5). In contrast, only a few sources have been traced for other resources, like marble, which were of local origin (6), and terra-cottas as shown here. This tendency must be further studied in the future. From the analyses carried out in this work, the following conclusions are drawn:

1. Despite the imperative use of high dilutions for the glass fused beads, the chemical analysis obtained from WDXRF was accurate enough to allow a provenance study. Following this procedure, the damage to future archaeological samples will be minimized.

2. Direct Rietveld quantitative phase analysis revealed several differences among the samples, useful to understand some physical properties such as the paler color of the samples fired at higher temperatures. This seems to be a consequence of the iron seizing in complex minerals such as pyroxenes. The firing temperatures were estimated for the 22 terra-cottas and they ranged between $\sim 700$ and $\sim 950{ }^{\circ} \mathrm{C}$.

3. Full Rietveld quantitative phase analysis, employing the innovative G-factor approach, allowed the quantification of the overall amorphous contents for 4 selected terra-cotta samples and 8 samples of a local clay tempered in a similar level and fired at increasingly higher temperatures. This external-standard method is advisable for processing large number of samples if enough material is available $(\sim 300 \mathrm{mg})$. The mineralogy and determined amorphous contents in the terra-cotta samples, close to $50 \mathrm{wt} \%$, are similar to those of the tempered clay fired at temperatures close to $900{ }^{\circ} \mathrm{C}$ and it shows the potential of this technique.

4. The mineralogical and chemical data are a powerful tool to assess provenance when combined with the knowledge of the local geology and ceramic production. Thus, local/ regional provenance for 17 samples has been assessed. Provenance for 5 additional samples (TRC005, TRC007, TRC011, TRC018, TRC019) could not have been traced, being likely foreign. Some samples, taking into account their mineralogy, seem to be from a further place from Malaga, in a similar geological area (e.g. TRC007), although a deeper characterization is needed.

\section{ACKNOWLEDGEMENTS}

We thank Mr. Carlos Jiménez, PANalytical B.V., and Mr. Emilio Ariño, Servicios Científico-Técnicos, Universidad de Oviedo, for the WDXRF analysis. Financial support from HAR2009-12547 (Spanish Ministry) and FQM-113 (Junta de Andalucía) research grants is acknowledged. JMC also thanks MICINN for his FPU studentship. The authors also want to thank the anonymous reviewers, whose comments have significantly improved the first version of the manuscript.

\section{REFERENCES}

1. Lowe, B. (2009): Roman Iberia. Economy, Society and Culture, Duckworth, London, UK.

2. Wilson, A. (2009): Approaches to quantifying Roman trade. In Bowman, A., Wilson, A (2009) (eds.), Quantifying the Roman Economy, Methods and problems, Oxford University Press, Oxford, UK, pp. 213-249.

3. Aubet, M.E. (2002): Notes on the economy of the Phoenician settlements in Southern Spain. In Bierling, M.R., Gitin, S. (2002) (eds.), The Phoenicians in Spain. An Archaeological review of the Eight-Sixth Centuries B.C.E. A collection of articles translated from Spanish, Eisenbrauns, Winona Lake, IN, USA, pp. 79-95.

4. Corrales, M. (2007): El Teatro Romano de Málaga: Evolución de un espacio, Mainake, 29: 53-76.

5. Arcas, A., Merino, I., Sánchez, L. (2008): Nuevas aportaciones a la distribución de productos cerámicos extrapeninsulares en la Malaca del principado y altoimperio, Mainake, 30: 413-436. 
6. Beltrán, J., Corrales, M., Fernández, L.E. (2008): Marmora del Teatro Romano de Malaca (Málaga). In Nogales, T., Beltrán, J. (2008) (eds.), Marmora Hispana: Explotación y uso de los materiales pétreos en la Hispania Romana, L'Erma di Bretschneider, Roma, Italia, pp. 261-284.

7. Ramos, M.L. (2008): Terracotas y elementos de coroplastia. In Bernal, D. Ribera, A. (2008) (eds.), Cerámicas hispanorromanas. Un estado de la cuestión, Universidad de Cádiz, Cádiz, España, pp. 775-785.

8. Dupré, X. (2005): Terracotas arquitectónicas prerromanas en Emporion, Empùries, 54: 103-123.

9. Ramallo, S. (1999): Terracotas arquitectónicas de inspiración itálica en la Península Ibérica. In Rico, C., Roldán, L., Bendala, M. (1999) (eds.), El ladrillo y sus derivados en la época romana. Monografías de Arquitectura romana 4, Servicio de Publicaciones. Universidad Autónoma de Madrid, Madrid, España, pp. 159-178.

10. López, J.L., Mora, B. (2002): Malaka y las ciudades fenicias en el occidente mediterráneo. Siglos VI a.C. - I d.C., Mainake, 24: 181-214.

11. Corrales, P. (2005): Aportaciones de la arqueología urbana para el conocimiento de la Málaga romana, Mainake, 27: 113-140.

12. Gijón, E. (2004): Las terracotas figuradas del Museo Nacional de Arte Romano de Mérida. Cuadernos Emeritenses 24, Museo Nacional de Arte Romano, Mérida, España.

13. Vaquerizo, D. (2002-2003): Dos antiguos hallazgos de terracotas figuradas en ambientes funerarios de Corduba. Revisión historiográfica y nueva propuesta de interpretación, Anales de Arqueología Cordobesa, 13-14: 311354.

14. Vaquerizo, D. (2004): Immaturi et innupti: terracotas figuradas en ambiente funerario de Corduba-Colonia Patricia. Instrumenta 15, Publicacions Edicions de la Universitat de Barcelona, Barcelona, España.

15. Instituto Geológico y Minero de España (IGME) (1978): Mapa geológico de España E. 1:50000, hoja 1053/67. Málaga-Torremolinos, Servicio de Publicaciones, Ministerio de Industria, Madrid, España.

16. Garzón, E., García-Rodríguez, I.G., Ruiz-Conde, A., Sánchez-Soto, P.J. (2009): Phyllites used as waterproofing layer materials for greenhouses crops in Spain: multivariate statistical analysis applied to their classification based on X-ray fluorescence analysis, X-Ray Spectrometry, 38: 429-438.

17. Garzón, E., Sánchez-Soto, P.J., Romero, E. (2010): Physical and geotechnical properties of clay phyllites, Applied Clay Science, 48: 307-318.

18. Igea, J., Lapuente, P., Saiz, M.E., Burillo, F., Bastida, J., Pérez-Arantegui, J. (2008): Estudio arqueométrico de cerámicas procedentes de cinco alfares celtibéricos del sistema ibérico central, Bol. Soc. Esp. Ceram. Vidr., 47 (1) 44-55.

19. Barrios Neira, J., Montealegre, L., López Palomo, L.A. (2010): Caracterización mineralógica y textural de Cerámicas Tartésicas de Ategua (Córdoba, España), Bol. Soc. Esp. Ceram. Vidr., 49 (5): 361-370.

20. Igea, J., Pérez-Arantegui, J., Lapuente, P., Saiz, M.E., Burillo, F. (2013) Producciones de cerámica Celtibérica procedentes del sistema Ibérico Central (España): Caracterización química y petrográfica, Bol. Soc. Esp. Ceram. Vidr., 52 (1): 1-14.

21. Buxeda i Garrigós, J., Mommsen, H., Tsolakidou, A. (2002): Alteration of $\mathrm{Na}, \mathrm{K}$ and $\mathrm{Rb}$ concentrations in Mycenaean pottery and a proposed explanation using X-ray diffraction, Archaeometry, 44 (2): 187-198.

22. Ricci, C., Borgia, I., Brunetti, B.G., Sgamelotti, A., Fabbri, B., Burla, M.C., Polidori, G. (2005): A study on late medieval transparent-glazed pottery and archaic majolica from Orvieto (central Italy), Archaeometry, 47 (3): 557570 .

23. Buxeda i Garrigos, J. (1999): Alteration and Contamination of Archaeological Ceramics: The Perturbation Problem, Journal of Archaeological Science, 26 (3): 295-313.

24. Aitchison, J. (2003): The statistical analysis of compositional data (2nd Ed.), The Blackburn Press, London-New York, UK-USA.

25. Everitt, B.S., Landau, S., Leese, M. (2001): Cluster Analysis (4 $4^{\text {th }}$ Ed.), Arnold, London, UK.

26. İssi, A., Kara, A. (2013): An investigation of pottery production technology for the West Slope wares from Dorylaion (Eskişehir/Turkey), Bol. Soc. Esp. Ceram. Vidr., 52 (1): 42-47.

27. Reventós, M.M., Clausell, J.V., Esteve, V., Delgado, J.M., Ochando, L.E., Rius, J., Martí, F., Amigó, J.M. (2002): Caracterización mineralógica de materias primas cerámicas por métodos cuantitativos de difracción de rayos X, Bol. Soc. Esp. Ceram. Vidr., 41 (6): 509-512.

28. Compaña, J.M., León-Reina, L., Aranda, M.A.G. (2010): Archaeometric characterization of Terra Sigillata Hispanica from Granada workshops, Bol. Soc. Esp. Ceram. Vidr., 49 (2): 113-119.

29. Pascual, C., Criado, E., Recio, P., Martinez, R., Aza, A.H. de, Valle, F.J Mañueco, C. (2011): La porcelana de sepiolita de Bartolomé Sureda (18021808). Investigación arqueométrica sobre la Real Fábrica de Buen Retiro, Bol. Soc. Esp. Ceram. Vidr., 50 (6): 311-328.

30. Rietveld, H.M. (1969): A profile refinement method for nuclear and magnetic structures, J. Appl. Crystallogr., 2: 65-71.

31. McCusker, L.B., Von Dreele, R.B., Cox, D.E., Louër, D., Scardi, P. (1999): Rietveld refinement guidelines, J. Appl. Crystallogr., 32: 36-50.
32. Martineau, R., Walter-Simonnet, A.V., Grobéty, B., Buatier, M. (2007) Clay resources and technical choices for neolithic pottery (Chalain, Jura, France): Chemical, mineralogical and grain-size analyses, Archaeometry, 49 (1): 23-52.

33. Gliozzo, E., Grassi, N., Bonanni, P., Meneghini, C., Tomei, M.A. (2011) Gemstones from Vigna Barberini at the Palatine hill (Rome, Italy), Archaeometry, 53 (3): 469-489.

34. Gliozzo, E., Cavari, F., Damiani, D., Memmi, I. (2012): Pigments and plasters from the Roman settlement of Thamusida (Rabat, Morocco), Archaeometry, 54 (2): 278-293.

35. Graetsch, H.A., Grünberg, J.M. (2012): Microstructure of flint and other chert raw materials, Archaeometry, 54 (1): 18-36.

36. Tite, M.S., Freestone, I.C., Wood, N. (2012): An investigation into the relationship between the raw materials used in the production of Chinese porcelain and stoneware bodies and the resulting microstructures, Archaeometry, 54 (1): 37-55.

37. De la Torre, A.G., Bruque, S., Aranda, M.A.G. (2001): Rietveld quantitative amorphous content analysis, J. Appl. Crystallogr., 34: 196-202.

38. Westphal, T., Füllmann, T., Pöllman, H. (2009): Rietveld quantification of amorphous portions with an internal standard. Mathematical consequences of the experimental approach, Powder Diffraction, 24 (3): 239-243.

39. O'Connor, B.H., Raven, M.D. (1988): Application of the Rietveld refinement procedure in assaying powdered mixtures, Powder Diffraction, 3 (1): 2-6.

40. Madsen, I.C., Scarlett, N.V.Y., Kern, A. (2011): Description and survey of methodologies for the determination of amorphous content via X-ray powder diffraction, Z. Kristallogr., 226: 944-955.

41. Aranda, M.A.G., De la Torre, A.G., Leon-Reina, L. (2012): Rietveld Quantitative Phase Analysis of OPC clinkers, cements and hydration products, Rev. Mineral. Geochem., 74: 169-209.

42. Ramón, J. (1995): Las ánforas fenicio-púnicas del Mediterráneo central y occidental. Instrumenta 2, Publicacions i Edicions de la Universitat de Barcelona, Barcelona, España.

43. Amadori, M.L., Fabbri, B. (1998): Produzione locale e importazioni di ceramiche fenicie da mensa (fine VIII - fine VII secolo a.C.) a Toscanos (Spagna Meridionale). In Acquaro, E., Fabbri B. (1998) (eds.), Produzione e circolazione della ceramica fenicia e punica nel Mediterraneo: Il contributo delle analisi archeometriche: Atti della $2^{a}$ Giornata di Archeometria della ceramica Ravenna, 14 Maggio 1998. University Press Bologna, Bologna, Italia, pp. 85-94.

44. González-Prats, A. (1986): Las importaciones y presencia fenicias en la Sierra de Crevillente (Alicante). In Del Olmo, G., Aubet M.E. (1986) (eds.), Los Fenicios en la Península Ibérica, Editorial Ausa, Sabadell, España, Vol. 2, pp. 279-302.

45. Cardell, C., Rodríguez-Gordillo, J., Morotti, M., Párraga, M. (1999) Arqueometría de cerámicas fenicias de "Cerro del Villar" (Guadalhorce, Málaga): Composición y procedencia. In Capel J. (1999) (ed.), Arqueometrí y Arqueología, Monográfica de Arte y Arqueologia, Universidad de Granada, Granada, España, pp. 107-120.

46. Behrendt, S., Mielke, D.P. (2011): Provenienzuntersuchungen mittels neutronenaktivierungsanalyse an Phönizischer keramik von der Iberischen Halbinsel und aus Marokko, Madrider Mitteilungen, 52: 139-237.

47. Martín-Ruiz, J.A. (2004): Los fenicios en Andalucía, Junta de Andalucía. Consejería de Cultura, Sevilla, España.

48. Maniatis, Y., Simopoulos, A., Kostikas, A. (1981): Moessbauer study of the effect of calcium content on iron oxide transformation in fired clays, J. Am. Ceram. Soc., 64 (5): 263-269.

49. Molera, J., Pradell, T., Vendrell-Saz, M. (1998): The colours of Ca-rich ceramic pastes: origin and characterization, Applied Clay Science, 13 (3): 187-202.

50. Riccardi, M.P., Messiga, B., Duminuco, P. (1999): An approach to the dynamics of clay firing, Applied Clay Science, 15 (3-4): 393-409.

51. Martín-Márquez, J., De la Torre, A.G., Aranda, M.A.G., Rincón, J.M. Romero, M. (2009): Evolution with temperature of crystalline and amorphous phases in porcelain stoneware, J. Am. Ceram. Soc., 92 (1): 229234.

52. Trindade, M. Dias, M.I, Coroado, J., Rocha, F. (2009): Mineralogica transformations of calcareous rich clays with firing: A comparative study between calcite and dolomite rich clays from Algarve, Portugal, Applied Clay Science, 42 (3-4): 345-355.

53. Gosselain, O.P. (1992): Bonfire of the enquiries. Pottery firing temperatures in Archaeology: What for?, Journal of Archaeological Science, 19: 243-259.

54. Compaña, J.M., Cabeza, A., Macías, J., Aranda, M.A.G., León-Reina, L. (in press): G-factor, a suitable tool for ancient ceramic characterization. Application to monitoring amphorae phase transformations in firing, Archaeometry, (ARCH-07-0119-2013).

Recibido: $08 / 11 / 2013$

Recibida versión corregida: 23/04/2014

Aceptado: 25/04/2014 